\title{
KIZILÖTESİ, MİKRODALGA, ULTRASES TEKNOLOJİLERİ VE KOMBİNASYONLARI KULLANILARAK MODİFİYE EDİLMİŞ DOĞAL BİYOPOLİMERLERİN ÇEŞİTLİ ÖZELLİKLERİ ÜZERİNE BİR DERLEME
}

\author{
Lale Acar ${ }^{1}$, Semin Özge Keskin ${ }^{1,2 *}$ \\ ${ }^{1}$ Kocaeli Üniversitesi Polimer Bilimi ve Teknolojisi, Umuttepe/Kocaeli, Türkiye \\ ${ }^{2}$ Kocaeli Üniversitesi İzmit MYO Gıda Teknolojisi, Kartepe/Kocaeli, Türkiye
}

Geliş / Received: 26.01.2021; Kabul / Accepted: 05.05.2021; Online bask1 / Published online: 14.05.2021

Acar, L., Keskin, S.Ö. (2021). Kızılötesi, mikrodalga, ultrases teknolojileri ve kombinasyonları kullanılarak modifiye edilmiş doğal biyopolimerlerin çeşitli özellikleri üzerine bir derleme. GIDA (2021) 46 (4) 785-802 doi: 10.15237/gida. GD21022.

Acar, L., Keskin, S.Ö. (2021). A review on various properties of natural biopolymers modified by infrared, microwave, ultrasound technologies and their combinations. GIDA (2021) 46 (4) 785-802 doi: 10.15237/gida. GD21022

\section{ÖZ}

Doğal biyopolimerler, gıda, ambalajlama, tekstil, otomotiv, tıp, ilaç, vb. birçok alanda kullanılan çevre dostu, yeşil polimerlerdir. Doğal biyopolimerlerin farklı teknolojiler kullanılarak modifiye edilmeleriyle fonksiyonellikleri geliștirilebilmektedir. Modifiye edilmiș doğal biyopolimerler, gıła sanayinde enkapsülasyon malzemesi ve yüksek performanslı yenilebilir film, kaplama veya fonksiyonel gida bileşeni olarak kullanılabilmektedir. Kızılötesi, mikrodalga, ultrases teknolojileri ve kombinasyonları, kendilerine özgü etki mekanizmalarını kullanarak doğal biyopolimerleri degrade ve depolimerize etmekte ve fonksiyonelliklerini olumlu yönde etkilemektedirler. Mikrodalga ve ultrases-mikrodalga teknolojileri kullanılarak ekstraksiyon ve enzimatik hidroliz gibi işlemlerin verimi arttırlabilmekte, işlem süresi kısaltılabilmekte ve elde edilen polimerlerin özellikleri iyileştirilebilmektedir. Bu makalede, kızılötesi, mikrodalga ve ultrases teknolojileri ve kombinasyonlarının etki mekanizmalarından kısaca bahsedilerek bu teknolojiler kullanılarak modifiye edilmiş doğal biyopolimerlerin çeşitli özellikleri derlenmiş, mikrodalga ve ultrases-mikrodalga teknolojilerinin ekstraksiyon, enzimatik hidroliz gibi işlemlerin verimliliği, işlem süresi ve elde edilen polimerlerin özellikleri üzerindeki etkilerine yer verilmiştir.

Anahtar kelimeler: Doğal biyopolimer, kızılötesi, kombinasyon, mikrodalga, modifikasyon, ultrases

\section{A REVIEW ON VARIOUS PROPERTIES OF NATURAL BIOPOLYMERS MODIFIED BY INFRARED, MICROWAVE, ULTRASOUND TECHNOLOGIES AND THEIR COMBINATIONS}

\begin{abstract}
Natural biopolymers are environmentally friendly, green polymers, used in various fields, such as food production, food packaging, textile, otomotive, medicine, drug, etc. Modification of natural biopolymers by use of different technologies can improve their functionalities. Modified natural biopolymers can be used as an encapsulation material, an ingredient of high performance edible film, coating or a functional food. Infrared, microwave and ultrasound and their combinations can degrade
\end{abstract}

\footnotetext{
*Yazışmalardan sorumlu yazar / Corresponding author

17: seminozgekeskin@gmail.com (1): (+90) $2623513286-87 / 127$

圆: (+90) 2623513288
}

Lale Acar; ORCID no: 0000-0002-5889-9843

Semin Özge Keskin; ORCID no: 0000-0002-4727-1508 
and depolymerize natural biopolymers and affect their functionalities in a positive manner, according to their specific action mechanisms. Ultrasound and ultrasound-microwave combination technologies can increase extraction and enzymatic hydrolysis yield, decrease process time and improve properties of polymers. In this paper, action mechanisms of infrared, microwave and ultrasound technologies were mentioned briefly, various properties of natural biopolymers modified by those technologies and effects of ultrasound and ultrasound-microwave combination technologies on yield, process time of extraction and enzymatic hydrolysis processes were featured.

Keywords: Natural biopolymer, infrared, combination, microwave, modification, ultrasound

\section{GİRIŞ}

Hayvan, bitki, mikroorganizma gibi biyolojik kaynaklardan elde edilen polimerler, doğal biyopolimerler olarak adlandırilırlar. Günümüzde doğal biyopolimerlere olan ilgi, biyouyumlulukları ve biyolojik olarak parçalanabilirlikleri nedeniyle gün geçtikçe artmaktadır (Bhatia., 2016; Balaji vd., 2018). Tüketiciler, petrol ve diğer yenilenemeyen kaynaklara bağımlilı̆̆1 azaltan, çevre dostu ürünler talep etmektedirler (Dangaran vd., 2009).

Biyopolimerlerin doğal haliyle işlenmesinin getirdiği teknolojik zorluklar ve kalite problemleri, çeşitli teknolojiler kullanılarak modifiye edilmelerini zorunlu kilmaktadır. Bu kapsamda, fiziksel teknolojiler, güvenli ve kolay kullanılabilir olmalarının yanı sıra sürdürülebilir ve çevre dostu olmalarından dolayı önemli bir yere sahiptir. Kızılötesi, mikrodalga, ultrases ve bunların kombine uygulamaları, fiziksel modifikasyon yöntemlerinden bazılarıdır. $\mathrm{Bu}$ teknolojiler kullanılarak polimer zincirleri arasındaki bağlar koparılmakta, polimerlerin molekül ağırlığ1, çözünürlük, termal stabilite vb. gibi birçok özelliğinde değişiklikler meydana getirilebilmektedir.

Kızılötesi radyasyon, 0.78 ile $1000 \mu \mathrm{m}$ arasındaki dalgaboyu aralı̆̆ında elektromanyetik dalgalar oluşturur (Riadh vd., 2015; Semwal ve Meera, 2020; Lee., 2021). Kizılötesi radyasyonu, elektromanyetik radyasyon spektrumunda, görünür sşı bölgesi $(0.38-0.78 \mu \mathrm{m})$ ile mikrodalga (1-1000 $\mu \mathrm{m})$ arasında bulunur. Kızı̈ötesi işınlar dalga boylarına göre kendi içerisinde üç bölgeye ayrilmaktadır. Bunlar, yakın kızılötesi (NIR) (0.78-1.4 $\mu \mathrm{m})$, orta kizılötesi (MIR) $(1.4-3.0 \mu \mathrm{m})$ ve uzak kızılötesi (FIR) (3.0-1000 $\mu \mathrm{m})$ radyasyonudur (Riadh vd., 2015; Lao vd., 2019; Lee, 2021; Rastogi, 2021). Ancak literatürde bu üç bölgeyi tanımlayan dalga boylarının alt ve üst sınırları küçük farklılıklar gösterebilmektedir (Yılmaz Tuncel ve Tuncel, 2016). Kizılötesi 1şınları bir materyalle temas ettiğinde, materyal tarafindan yansıtılabilir, materyalin içinden geçebilir veya materyal tarafindan absorbe edilebilir. Kızılötesi 1şınları materyal tarafindan absorbe edildiğinde, atomlar arası bağlarda titreşimsel değişikliklere neden olmaktadır. Kızılötesi 1şınlarının yarattığı titreşim ve sürtünmeden dolayı materyalin yüzeyinde 1S1 üretilmekte; 1s1, yüzeyden merkeze kademeli olarak iletilmekte böylece materyalin içi 1sittlmaktadır. (Aboud vd., 2019; Yadav vd., 2020; Rastogi, 2021).

Kızılötesi 1sıtma işlemi, daha kısa uygulama süresi (yüksek 1s1 transfer katsayıs1), daha yüksek enerji verimliliği, tek tip ürün sıcaklı̆̆ı, temiz çalışma, daha düşük enerji maliyeti gibi çeşitli avantajlara sahip olduğundan tarımsal ürünlerin işlenmesinde yaygin olarak kullanilmaktadır (Uraives ve Choomjaihan, 2019; Rastogi, 2021). Özellikle son yıllarda gida işlemede kurutma, pişirme, kavurma, haşlama, pastörizasyon ve çözme gibi birçok işlem için kullanılmaktadır (Rastogi, 2021). Kızılötesi 1sıtmanın kullanıldığı bir diğer alan ise biyopolimerlerin modifikasyonudur. Örneğin, doğal nişastalar, yüksek kesme hızı ve kuvvetine, düşük asitliğe ve yüksek-düşük sıcaklıklara karş1 dayanıksızdır. Doğal nişastaların özelliklerini geliştirmek amaciyla modifikasyona ihtiyaç duyulmaktadır (İsmailoğlu ve Başman, 2015). Kızılötesi 1sıtma da nişasta modifikasyonunda kullanılan bir teknolojidir (İsmailoğlu ve Başman, 2015, 2016; Çengelköy Köz, 2019). Farklı dalgaboylarındaki kızılötesi radyasyonla nişastanın granül yapısının ve reolojik özelliklerinin değiştiği ve nişastanın elde edildiği kaynağa bağlı olarak bu değişimlerin farklılık gösterdiği belirtilmektedir (Guo vd., 2020; Semwal ve Meera, 2020). Kızılötesi ısıtmada, uygulama sıcaklık ve süresinin 
arttırılmasıyla tapiyoka nişastasının şişme gücünün ve sudaki çözünürlügünün arttığ1 ve nişastanın iyotla verdiği rengin değişim gösterdiği bulunmuştur (Uraives ve Choomjaihan, 2019). Tavlanmış buğday ve mısır nişastaları ile yapılan çalışmalarda, kızılötesi ısıtma işleminin, nişastaların jelatinizasyon derecesini, kristalinitesini, reolojik özelliklerini ve sudaki çözünürlüğ̈unü etkilediği tespit edilmiştir (İsmailoğlu ve Başman, 2015, 2016; Çengelköy Köz, 2019). Elde edilen sonuçlar, kızılötesi ısıtmanın nişasta modifikasyonunda etkili bir yöntem olduğunu göstermektedir.

Mikrodalgalar, elektromanyetik spektrumun radyo dalgaları ile kızılötesi ışınları arasında kalan, frekanslar1 $300 \mathrm{MHz}-300 \mathrm{GHz}$, dalga boylar1 $1 \mathrm{~mm}-1 \mathrm{~m}$ arasinda olan iyonize edici olmayan elektromanyetik dalgalardır (Rattanadecho ve Makul, 2016; Qin vd., 2016; Martins vd., 2019; Verma vd., 2020). Mikrodalgayı soğuran malzemelerde 1sınma, "dipol etkileşim" ve "iyonik iletim" olmak üzere iki mekanizma ile olmaktadır. Dipol etkileşimde, dipol momentli malzemeler (örneğin su molekülü), elektrik alan altında dönme hareketi yapmakta, bu dönme hareketi sonucu oluşan sürtünme kuvveti, moleküllerin enerji kazanıp isınmasına neden olmaktadır. İyonik iletimde iyonlar, mikrodalganın elektrik alanının neden olduğu polarite değişimine bağlı olarak hareket etmekte ve çarpışmaktadırlar. Bu çarpışma sonucu açığa çıkan kinetik enerji, 1s1 enerjisine dönüşmekte ve iyon içeren madde 1sinmaktadır (Mello vd., 2014; Martins vd., 2019; Verma vd., 2020). Mikrodalga 1sitma ile polimer zincirleri arasındaki hidrojen bağları kırılmakta ve moleküller arası çapraz bağlanmalar güçlenmektedir (Wang vd., 2013; Wang vd., 2016; Sun vd., 2018). Mikrodalga radyasyonu, homojen 1sı dağılımı, daha iyi penetrasyon derinliği, daha kısa bir işlem süresi, daha yüksek verim, daha iyi ürün kalitesi, düşük maliyet, daha yüksek tekrarlanabilirlik sağlayan çevre dostu, daha temiz, daha yeşil bir yaklaşım sunması gibi avantajları nedeniyle gıda sanayi başta olmak üzere (firnnlama, pişirme, çözme, haşlama, dehidrasyon, pastörizasyon, sterilizasyon, temperleme gibi) bir çok sektörde giderek daha fazla kullanım alanı bulmaktadır (Keskin, 2003; Keskin vd., 2004a, 2004b, 2005; Singh vd., 2012; Desbrières vd., 2014; Rattanadecho ve Makul, 2016; Wang vd., 2016; Yang vd., 2017; Mizutani vd., 2019).

Literatürde yapılan çalışmalar incelendiğinde, mikrodalga 1sıtmanın çeşitli kaynaklardan elde edilen nişastaların reolojik ve termal özelliklerini, kristal yapısını ve sindirilebilirliğini etkilediği görülmektedir (Stevenson, 2005; Anderson ve Guraya, 2006; Ma vd., 2015; Nadiah vd., 2015; Oyeyinka vd., 2019; Kumar vd., 2020). Mikrodalga isıtmanın yağların kimyasal kaliteleri ve oksidatif stabiliteleri üzerine etkilerini inceleyen çalısmalarda, mikrodalga ısıtmanın yağların serbest yağ asidi profillerinde ve oksidatif stabilitelerinde değişime neden olduğu ve bu değişimin seviyesinin yağın elde edildiği kaynağa bağlı olduğu belirtilmiştir (Tan vd., 2001; Pop, 2018; Arifoğlu ve Öğütçü, 2019; Mizutani vd., 2019; Karrar vd., 2020).

Ultrases işlemi, çeşitli biyopolimerleri depolimerize etmek için kullanılan yöntemlerden bir diğeridir. Ultrases işlemi, polimerlerin yapısını fiziksel olarak bozabilecek veya bileşenler arasında belirli kimyasal reaksiyonların oluşmasina yol açabilecek basınç, kayma kuvveti ve 1S1 üretmektedir. İnsan kulağı, $16 \mathrm{~Hz}$ ile $20 \mathrm{kHz}$ frekansları arasındaki dalgasal enerjiyi ses olarak alg1layabilir (Kasaai, 2013; Guimaraes vd., 2018; Bhargava vd., 2021). 20 kHz' den fazla olan, insan kulağ1 tarafindan algılanamayacak kadar yüksek ses frekansı bölgesine de ultrases bölgesi adı verilmektedir (Firouz vd., 2019; McKenzie vd., 2019). Diğer bir ifadeyle ultrases, saniyede 20000 veya daha fazla ses dalgasından oluşan mekanik bir enerjidir (Türk, 2013; Virkutyte, 2015). Siv1 içine uygulanan ultrases dalgaları, sürekli şekilde basınç ve genleşme döngüleri oluşturmaktadır. Bu döngüler sırasında moleküller birbirine doğru itilir ve uzaklaştırllır. Uzaklaşma sırasında ultrases kuvveti yüzey gerilimi kuvvetini aştığında sıv1 içinde kabarcıklar oluşmaktadır. Bu kabarcıkların oluşumuna ve gelişmesine 'kavitasyon' denir (Gallo vd., 2018; Firouz vd., 2019). Bu işlem sonucunda, polimer zincirleri arasindaki kovalent ve kovalent olmayan bağlar kırilmakta ve polimer parçalanmaktadır (Akyüz, 2010). 
Çeşitli uygulamalarda kullanılan ultrases dalgaları, yoğunluk ve frekansa bağl1 olarak, düşük ve yüksek yoğunluklu ultrases olarak iki kategoriye ayrilabilir. Yüksek frekanslarda ve düşük güçlerde ultrases dalgaları fiziksel ölçümlerde, özellikle tıbbi ve diagnostik alanlar için kullanılmaktadır, "tanısal dalgalar" olarak da tanımlanmaktadır. Yüksek yoğunluklu ve düşük frekanslı ultrases dalgalar1, polimerlerin fiziksel, mekanik ve kimyasal özellikleri üzerinde önemli etkilere neden olan frekanslar1 20 ila $100 \mathrm{kHz}$ arasinda değişen, yoğunlukları 10 ila $1000 \mathrm{~W} / \mathrm{cm}^{2}$ aralığında olan dalgalardır (Gallo vd., 2018; Firouz vd., 2019; Bhargava vd., 2021). Doğal biyopolimerleri modifiye etmek için de yüksek yoğunluklu ultrases uygulaması kullanılabilmekte ve bu uygulama, giderek daha fazla bilimsel araştırmanın konusu olmaktadır (Arzeni vd., 2012; Vera vd., 2020).

Ultrases uygulaması, yüksek etkinliği, düşük teknoloji gereksinimi ve diğer geleneksel tekniklerle karşılaştırıldığında kısa işlem süresi, düşük işletme ve bakım maliyeti, iyileştirilmiş kalite özellikleri ve daha yeşil bir yaklaşım sunması gibi avantajları nedeniyle gıda sanayi başta olmak üzere ekstraksiyon, homojenizasyon, kristalizasyon, pastörizasyon, seperasyon, filtrasyon, vb. uygulamaların performanslarinin arttırılmasinda kullanılmaktadır (Patist ve Bates, 2008; Virkutyte, 2015; Zhu, 2015; Gallo vd., 2018; Bhargava vd., 2021). Ayrica ultrases uygulamas1 uzun polimerik makromoleküllerin parçalanması için ekonomik ve basit araçlardan biridir (Souza vd., 2013). Ultrases uygulamasının nişasta ve proteinler üzerine etkisini araştıran çalışmalar incelendiğinde, nişasta ve proteinlerin birçok özelliğinin ultrases koşullarına bağlı olarak değiştiği görülmektedir. Nişasta üzerine yapılan çalışmalar, ultrases işleminin nişasta granülünde mikroyapısal değişimlere neden olduğunu, nişasta granüllerinin kristalinitelerini azalttığını, çözünürlüklerini ve su tutma kapasitelerini arttırdığını göstermektedir (Jambrak vd., 2010; Monroy vd., 2018). Yüksek yoğunluklu ultrases uygulamasının proteinlerin özelliklerine etkisi dikkate alındığında ise protein solüsyonlarının viskozitelerinin, kıvam indekslerinin azaldığı, çözünürlüklerinin ve yüzey hidrofobisitelerinin arttı̆̆1 bildirilmiş̧ir (Arzeni vd., 2012; Amiri vd., 2018).

Kızılötesi, mikrodalga ve ultrases teknolojileri, polimerlerin modifikasyonunda tek başlarına kullanılabildikleri gibi kızılötesi-mikrodalga, ultrases-mikrodalga şeklinde kombinasyon olarak da uygulanabilmektedirler. Böylece sinerjistik bir etki oluşturularak polimerlerin yapisal ve fonksiyonel özelliklerinde değişiklikler meydana getirilebilmektedir (Çengelköy Köz, 2019). Kızılötesi-mikrodalga kombinasyon uygulamasının nişasta özelliklerine etkisini araştıran çalışmalara bakııldığında, nişastanın fizikokimyasal özelliklerinden su emme kapasitesinde, 1şık geçirgenliğinde artış meydana geldiği, amiloz içeriği, $\mathrm{pH}$ ve sinerezis özelliklerinde ise azalma olduğu bildirilmiştir (Shah vd., 2016). Nişastaların fiziksel, optik, morfolojik, termal özellikleri ile X-1şını kırınım desenleri, modifikasyon işlemi ile belirgin bir şekilde değişmiştir (Çengelköy Köz, 2019). Ultrases-mikrodalga kombinasyon uygulamalar1, nişasta, guar gam gibi polimerlerin depolimerizasyonunda, çeşitli kaynaklardan elde edilen protein ve nişastaların fiziksel ve kimyasal modifikasyonunda, yağl1 tohumlardan yağ ekstraksiyonunda kullanılan etkin yöntemlerdir (Liu vd., 2012; Prajapat ve Gogate, 2015; Hassan vd., 2017; Li vd., 2020; Noman vd., 2020; Wang vd., 2020).

$\mathrm{Bu}$ teknolojilerle modifiye edilmiş doğal biyopolimerler, gida sanayinde enkapsülasyon malzemesi ve yüksek performanslı yenilebilir film, kaplama veya fonksiyonel gida bileşeni olarak kullanılabilmektedir (Çengelköy Köz, 2019; Cui ve Zhu, 2021).

\section{Kızılötesi teknolojisinin doğal biyopolimerler üzerine etkisi}

Kızılötesi 1sıtmanın, nişastanın fiziksel modifikasyonunda kullanılabilecek etkin bir yöntem olduğu çeşitli bilimsel çalışmalarla ortaya konmuştur (Çizelge 1). Farklı güç ve sürelerde kızılötesi uygulaması, farklı nem düzeylerine tavlanmış mısır ve buğday nişastası örneklerinin; termal, reolojik, x ışını kırınım deseni, renk ve sudaki çözünürlük gibi özelliklerinde değişimler 
meydana getirmiştir (İsmailoğlu ve Başman, 2015, 2016; Çengelköy Köz, 2019). Kızılötesi ısıtmanın nişasta özellikleri üzerindeki etkisi, nişastanın elde edildiği kaynağa, kızı̈ötesi radyasyon dalgaboyuna ve 1sıl işlem koşullarına bağlı olarak değişiklik göstermiştir (İsmailoğlu ve Başman, 2015, 2016; Çengelköy Köz, 2019; Uraives ve Choomjaihan, 2019; Guo vd., 2020).

Çizelge 1. Kızılötesi teknolojisinin doğal biyopolimerler üzerine etkisi

\begin{tabular}{|c|c|c|c|c|}
\hline Biyopolimer & $\begin{array}{l}\text { Biyopolimer } \\
\text { tipi/kaynağ1 }\end{array}$ & $\begin{array}{l}\text { Kızılötesi Uygulama } \\
\text { Koşulları }\end{array}$ & $\begin{array}{l}\text { Biyopolimer Üzerine } \\
\text { Etkileri }\end{array}$ & Kaynak \\
\hline Nişasta & $\begin{array}{l}\% 20 \text { ve } \\
\% 30 \text { neme } \\
\text { tavlanmiş } \\
\text { misır ve } \\
\text { buğday } \\
\text { nişastası }\end{array}$ & $\begin{array}{l}30,60 \text { ve } 90 \mathrm{dk}, 550 \text { ve } \\
730 \mathrm{~W}\end{array}$ & $\begin{array}{l}\text { Termal, reolojik, x 1şını } \\
\text { kırınım deseni, sudaki } \\
\text { çözünürlük gibi } \\
\text { özelliklerde değissiklik, } \\
\text { kızı̈ötesi 1sıtma gücünün } \\
\text { arttırılmasıyla kristalinite } \\
\text { değerlerinde artış, } \\
\text { viskozite değerlerinde } \\
\text { azalış }\end{array}$ & $\begin{array}{l}\text { İsmailoğlu ve } \\
\text { Başman, } \\
\text { 2015, } 2016\end{array}$ \\
\hline Nişasta & $\begin{array}{l}\text { \%15 ve } \\
\% 25 \text { neme } \\
\text { tavlanmış } \\
\text { misır } \\
\text { nişastası } \\
\end{array}$ & $\begin{array}{l}30,15,15 \mathrm{dk}, \\
\% 20,30,50 \text { güç }\end{array}$ & $\begin{array}{l}\text { Nişastanın fiziksel, reolojik } \\
\text { ve termal özelliklerinde } \\
\text { iyileşme }\end{array}$ & $\begin{array}{l}\text { Çengelköy } \\
\text { Köz, } 2019\end{array}$ \\
\hline Nişasta & $\begin{array}{l}\text { Tapioka } \\
\text { nişastas1 }\end{array}$ & $\begin{array}{l}170,190 \text { ve } 210{ }^{\circ} \mathrm{C} \text {, } \\
1100,1320 \text { ve } 1540 \mathrm{~W}, \\
20 \text { saat boyunca her } 2 \\
\text { saatte bir ölçüm }\end{array}$ & $\begin{array}{l}\text { Nişasta granüllerinin şişme } \\
\text { gücü ile renk değerinde } \\
\text { artış, nişastanın iyotla } \\
\text { verdiği mavi renk } \\
\text { değerinde azalış }\end{array}$ & $\begin{array}{l}\text { Uraives ve } \\
\text { Choomjaihan, } \\
2019\end{array}$ \\
\hline Nişasta & $\begin{array}{l}\text { Pirinç, } \\
\text { misır, } \\
\text { buğday, } \\
\text { patates } \\
\text { nişastası }\end{array}$ & $\begin{array}{l}\text { Uzak } \\
\text { radyasyonu, } \\
50{ }^{\circ} \mathrm{C}, 12 \mathrm{sa}\end{array}$ & $\begin{array}{l}\text { Granüler şişmede azalma, } \\
\text { patates nişastasında uzun } \\
\text { vadede stabil yapı, pirinç } \\
\text { ve buğday nişastasının } \\
\text { yayılabilirlik özelliklerinde } \\
\text { gelișme }\end{array}$ & Guo vd., 2020 \\
\hline
\end{tabular}

Kizılötesi 1sıtma sicaklığ1 ve süresi arttıkça tapiyoka nişasta granüllerinin şişme gücü ile toplam renk farkı değerleri artmış, iyotla verdiği mavi renk değerleri azalmıştır. Bir diğer çalışmada, uzak kızılötesi radyasyon uygulamas1, patates nişastasının yapısal dayanımını geliştirip, uzun vadede daha stabil bir yapı kazanmasını sağlarken pirinç ve buğday nişastalarında yayılabilirlik özelliğini geliştirmiştir (Guo vd., 2020).

\section{Mikrodalga teknolojisinin doğal biyopolimerler üzerine etkisi}

Mikrodalga 1sıtma, işlem koşullarına ve nişasta çeşidine ve özelliklerine bağlı olarak nişastaların fiziksel, termal ve reolojik özelliklerini değiştirmiştir (Çizelge 2). 0.17 veya $0.5 \mathrm{~W} / \mathrm{g}$ güçlerinde mikrodalga uygulamasıyla \%15-40 neme sahip misır nişastasının bütün çirişlenme parametreleri azalmış, çirişlenme sıcaklığ 1 ise 0.5 $\mathrm{W} / \mathrm{g}$ mikrodalga uygulamasıyla artmışır (Stevenson vd., 2005). \%20 neme tavlanmış mumsu ve mumsu olmayan pirinç nişastalarına mikrodalga uygulaması, nişastaların sindirilebilirlik ve morfolojik özelliklerini çok etkilememekle birlikte nişastaların reolojik özelliklerinde önemli değişikliklere neden olmuştur. Mikrodalga uygulamasindan sonra mumsu nişasta, amilopektin zincirlerinin tekrar düzenlenmesinden kaynaklı daha yoğun bir yapıya kavuşmuştur (Anderson ve Guraya, 2006). 
Mikrodalga 1sıtma, patates nişastası-su sisteminin fiziksel özelliklerini etkilemiş, nişastaların partikül boyutunu, polarizasyon ve termal özelliklerini değiştirmiş̧ir (Ma vd., 2015). Patates ve tapyoka nişastası süspansiyonlarına mikrodalga uygulamasıyla nişastaların çirişlenme sıcaklığı ve çiriş stabilitesi ile amiloz içeriği ve şişme gücü artmış, suda çözünürlük ve jelatinizasyon entalpisi değerleri düşmüsstür (Nadiah vd., 2015). Diğer yandan elde edilen SEM görüntüleri, nişasta granüllerinin tahrip olduğunu, nişastaların çift kırınım özelliklerini kaybettiklerini göstermiştir. Mikrodalga 1sıtma, yumru ve kök nişastalar üzerinde farklı etkiler oluşturmuştur (Nadiah vd., 2015). Farklı güç ve sürelerde mikrodalga uygulaması, darı nişastasının çirişlenme kurve tipini, B-tipinden C-tipine değiştirmiş, kristallenme başlangıç sıcaklığını ve in vitro enzimatik sindirilebilirliği arttırmış, şişme gücü ve şeffaflı̆̆1 ile jelatinizasyon entalpisini düşürmüştür (Li vd., 2019). Ayrıca mikrodalga uygulamas1, dar1 nişastas1 granüllerinin orijinal görünümünü yok etmiş ve daha küçük ve ince tabakalı jel bloklarının oluşumuna neden olmuştur. Mikrodalga uygulama süresinin artışı, Bambara yerfıstığ1 nişastasının şişme gücünü ve viskozitesini azaltmıs, amiloz içeriği ve jelatinleşme sıcaklıklarını ise arttırmıstır (Oyeyinka vd., 2019). Mikrodalga 1şınlama-retrogradasyon uygulaması, mısır nişastası (A-tipi kristallik), patates nişastası (B-tipi) ve kestane nişastasının (C-tipi) fizikokimyasal ve sindirilebilirlik özelliklerini değiştirmiştir. Nişastaların sindirilebilirliği, mikrodalga 1şıması ve retrogradasyondan 8 saat sonrasına kadar artmıs, 24 saatlik retrogradasyondan sonra, nişastanın sindirilebilirliği azalmıştır. Modifiye nişastaların dirençli nişasta içerikleri, doğal nişastaların dirençli nişasta içeriklerinden daha yüksek bulunmuştur (Wang vd., 2019). Sabit güç ve farklı sürelerde mikrodalga uygulaması, patates nişastasının fizikokimyasal, morfolojik, yapısal ve reolojik özelliklerini etkilemiştir (Kumar vd., 2020). Mikrodalga uygulama süresi arttıkça patates nişastalarının su emme kapasitesinde artış, yağ emme kapasitesinde düşüş ve viskozite değerlerinde değişim gözlenmiştir.

Çizelge 2. Mikrodalga teknolojisinin doğal biyopolimerler üzerine etkisi

\begin{tabular}{|c|c|c|c|c|}
\hline Biyopolimer & $\begin{array}{l}\text { Biyopolimer } \\
\text { tipi/kaynağ1 }\end{array}$ & $\begin{array}{l}\text { Mikrodalga } \\
\text { Uygulama Koşulları }\end{array}$ & Biyopolimer Üzerine Etkileri & Kaynak \\
\hline Nişasta & $\begin{array}{l}\text { \%15-40 neme } \\
\text { sahip misır } \\
\text { nişastası }\end{array}$ & $\begin{array}{l}0.17 \text { veya } 0.5 \mathrm{~W} / \mathrm{g} \\
\text { mikrodalga } \\
\text { radyasyonu, } 1 \mathrm{~h} \text { süre }\end{array}$ & $\begin{array}{l}\text { Çirişlenme parametrelerinde } \\
\text { azalış, güç uygulamasının artması } \\
\text { ile çirişlenme sıcaklığında artış }\end{array}$ & $\begin{array}{l}\text { Stevenson } \\
\text { vd., } 2005\end{array}$ \\
\hline Nişasta & $\begin{array}{l}\text { \%20 neme } \\
\text { tavlanmış } \\
\text { mumsu ve } \\
\text { mumsu olmayan } \\
\text { pirinç nişastası }\end{array}$ & $\begin{array}{l}270,540,810,1080 \\
1350 \mathrm{~W} \text { güç, } 0 \text { ve } \\
60 \mathrm{dk}\end{array}$ & $\begin{array}{l}\text { Sindirilebilirlik ve morfolojik } \\
\text { özelliklerinde çok az etki, } \\
\text { nişastaların reolojik özelliklerinde } \\
\text { önemli değişim }\end{array}$ & $\begin{array}{l}\text { Anderson } \\
\text { ve Guraya, } \\
2006\end{array}$ \\
\hline Nişasta & Patates nişastası & $\begin{array}{l}2450 \mathrm{MHz}, 70 \mathrm{~s} \text { için } \\
1.000 \mathrm{~W} \text { ssitma; } 50 \mathrm{~s} \\
\text { için } 350 \mathrm{~W} \text { 1sitma; } \\
25 \mathrm{~s} \text { için } 650 \mathrm{~W} \\
\text { 1sitma }\end{array}$ & $\begin{array}{l}\text { Nişastaların partikül boyutu, } \\
\text { polarizasyon ve termal } \\
\text { özelliklerinde değişim }\end{array}$ & $\begin{array}{l}\text { Ma vd., } \\
2015\end{array}$ \\
\hline Nişasta & $\begin{array}{l}\text { Patates ve } \\
\text { tapioka nişastası }\end{array}$ & $\begin{array}{l}2450 \mathrm{MHz}, 1000 \mathrm{~W} \\
\text { güç, } 50 \text { ve } 60^{\circ} \mathrm{C}\end{array}$ & $\begin{array}{l}\text { Mikrodalga 1sıtma ile nişasta } \\
\text { süspansiyonlarının çirişlenme } \\
\text { sıcaklığında ve çiriş stabilitesinde, } \\
\text { amiloz içeriğinde ve şişme } \\
\text { gücünde artış, suda çözünürlük ve } \\
\text { jelatinizasyon entalpisi } \\
\text { değerlerinde düşüş, patates } \\
\text { nişastasının kristal yapısında } \\
\text { değişim }\end{array}$ & $\begin{array}{l}\text { Nadiah vd., } \\
2015\end{array}$ \\
\hline
\end{tabular}


Çizelge 2. devam

\begin{tabular}{|c|c|c|c|c|}
\hline Biyopolimer & $\begin{array}{l}\text { Biyopolimer } \\
\text { tipi/kaynağ1 }\end{array}$ & $\begin{array}{l}\text { Mikrodalga } \\
\text { Uygulama Koşulları }\end{array}$ & Biyopolimer Üzerine Etkileri & Kaynak \\
\hline Nişasta & Darı nişastası & $\begin{array}{l}2450 \mathrm{kHz}, 700 \mathrm{~W} \\
\text { güç, 30, 60, } 90 \mathrm{ve} \\
120 \mathrm{~s}\end{array}$ & $\begin{array}{l}\text { Darı nişastasının çirişlenme kurve } \\
\text { tipinin B-tipinden C-tipine } \\
\text { değişme, kristallenme başlangıç } \\
\text { sıcaklığında ve in vitro enzimatik } \\
\text { sindirilebilirliğinde artış, şişme } \\
\text { gücü, şeffaflı̆̆ı ile jelatinizasyon } \\
\text { entalpisinde düşüş }\end{array}$ & Li vd., 2019 \\
\hline Nişasta & $\begin{array}{l}\text { Bambara } \\
\text { yerfistığ1 } \\
\text { nişastas1 }\end{array}$ & $\begin{array}{l}2450 \mathrm{MHz} \text { frekans, } \\
700 \mathrm{~W}, 0,10,30 \text { ve } \\
60 \mathrm{~s}\end{array}$ & $\begin{array}{l}\text { Uygulama süresinin artmasıyla } \\
\text { nişastanın şişme gücünde azalma, } \\
\text { amiloz içeriği ve jelatinleşme } \\
\text { sıcaklıklarında artış, viskozite } \\
\text { değerlerinde azalış }\end{array}$ & $\begin{array}{l}\text { Oyeyinka } \\
\text { vd., } 2019\end{array}$ \\
\hline Nişasta & $\begin{array}{l}\text { Misır, patates, } \\
\text { kestane nişastas1 }\end{array}$ & $\begin{array}{l}2450 \mathrm{MHz}, 120 \mathrm{~mA} \text {, } \\
90 \mathrm{~s}\end{array}$ & $\begin{array}{l}\text { Nişastaların sindirilebilirliğinde } \\
\text { mikrodalga 1şıması ve } \\
\text { retrogradasyondan } 8 \text { saat } \\
\text { sonrasına kadar artış, modifiye } \\
\text { nişastaların dirençli nişasta } \\
\text { içeriklerinde artış }\end{array}$ & $\begin{array}{l}\text { Wang vd., } \\
2019\end{array}$ \\
\hline Nişasta & Patates nişastas 1 & $\begin{array}{l}2450 \mathrm{MHz} \text { frekans, } \\
300 \mathrm{~W}, \\
1,3 \text { ve } 5 \mathrm{dk}\end{array}$ & $\begin{array}{l}\text { Uygulama süresi ile su emme } \\
\text { kapasitesinde artış, yağ emme } \\
\text { kapasitesinde azalış ve viskozite } \\
\text { değerlerinde değişim }\end{array}$ & $\begin{array}{l}\text { Kumar vd., } \\
2020\end{array}$ \\
\hline Lipid & $\begin{array}{l}\text { Misır ve soya } \\
\text { fasulyesi yağ1 }\end{array}$ & $\begin{array}{l}2450 \mathrm{~Hz} \text { frekans, } \\
900 \mathrm{~W} \text { güç, } \\
4,8,12,16 \text { ve } 20 \mathrm{dk}\end{array}$ & $\begin{array}{l}\text { Belirli bir mikrodalga güç seviyesi } \\
\text { için, DSC eğrisi parametreleri ve } \\
\text { 1sıtma periyotları arasında iyi bir } \\
\text { korelasyon }\end{array}$ & $\begin{array}{l}\text { Tan vd., } \\
2001\end{array}$ \\
\hline Lipid & $\begin{array}{l}\text { Aspir ve kolza } \\
\text { tohumu yağ1 }\end{array}$ & 1,3 ve $5 \mathrm{dk}$ & $\begin{array}{l}5 \text { dakika mikrodalga uygulaması } \\
\text { ile yağların peroksit indeksinde } \\
\text { artış, çoklu doymamış yağ asidi } \\
\text { profillerinde değişim }\end{array}$ & Pop, 2018 \\
\hline Lipid & $\begin{array}{l}\text { F1nd1k, kanola } \\
\text { ve misır yağ1 }\end{array}$ & $\begin{array}{l}2450 \mathrm{MHz}, 1200 \mathrm{~W} \\
0,3,5,10,15,20 \mathrm{ve} \\
30 \mathrm{dk}\end{array}$ & $\begin{array}{l}\text { Yağların serbest yă̆ asitliği, } \\
\text { peroksit değeri, konjüge dien ve } \\
\text { konjüge trien değerlerinde artış, } \\
\text { oksidatif indüksiyon sürelerinde } \\
\text { düşüş }\end{array}$ & $\begin{array}{l}\text { Arifoğlu ve } \\
\text { Öğütcü, } \\
2019\end{array}$ \\
\hline Protein & Soya sütü & $\begin{array}{l}2450 \mathrm{MHz} \text { frekans, } \\
70,85 \text { ve } 100^{\circ} \mathrm{C}, 2, \\
6 \text { ve } 10 \mathrm{dk}\end{array}$ & $\begin{array}{l}\text { Soya sütünün sindirilebilirliğinde } \\
\text { artış, tripsin inhibitörlerinin } \\
\text { aktivitesinde azalış }\end{array}$ & $\begin{array}{l}\text { Vanga vd., } \\
2020\end{array}$ \\
\hline $\begin{array}{l}\text { Protein ve } \\
\text { yağ }\end{array}$ & $\begin{array}{l}\text { Soya fasulyesi } \\
\text { tohumu }\end{array}$ & $500 \mathrm{~W}, 10,30,40 \mathrm{~s}$ & $\begin{array}{l}\text { Proteinlerin kısmi denatürasyonu, } \\
\text { tohum içindeki yağın tohumdan } \\
\text { daha kolay ekstrakte edilebilmesi }\end{array}$ & $\begin{array}{l}\text { Mizutani } \\
\text { vd., } 2019\end{array}$ \\
\hline Lipid & Gurum tohumu & $\begin{array}{l}2450 \mathrm{MHz} \text { frekans, } \\
800 \mathrm{~W}, 2,4 \text { ve } 6 \mathrm{dk}\end{array}$ & $\begin{array}{l}\text { Mikrodalga 1sıtma süresinin } \\
\text { artmasıyla, yağın renk değerinde } \\
\text { artma, kimyasal kalite ve oksidatif } \\
\text { stabilitesinde iyileşme }\end{array}$ & $\begin{array}{l}\text { Karrar vd., } \\
2020\end{array}$ \\
\hline
\end{tabular}


Mikrodalga 1sıtma, yağların kalitelerini ve yağ asidi profillerini, 1sıl işlem koşullarına, yağın özelliklerine ve çeşidine bağlı olarak farklı şekillerde etkilemiştir (Çizelge 2). Tan vd. (2001) yaptıkları çalışmada, mikrodalga uygulama zamanı ve gücünün iki bitkisel yağın (misır yağı ve soya fasulyesi yağı) 1sıl özellikleri ve kalitesi üzerindeki etkisini incelemiş ve mikrodalgada 1sıtılmış yağlarda DSC eğrisi parametreleri ile diğer standart kimyasal yöntemler (peroksit değeri, anisidin değeri, serbest yağ aside içeriği, iyot değeri ve C18:2/C16:0 pik alan oranı) arasındaki ilişkiyi araştırmışlardır. Elde edilen deneysel veriler, belirli bir mikrodalga güç seviyesi için, DSC eğrisi parametreleri ve 1sitma periyotları arasında iyi bir korelasyon olduğunu göstermiştir. Farklı sürelerle uygulanan mikrodalga 1sitma, aspir ve kolza tohumu yağlarının kalitelerini (peroksit değeri, iyot değeri, refraktif indeks, asit değeri, nem içeriği) ve yağ asidi profillerini etkilemiş̧ir. 5 dakika mikrodalga uygulaması, iki yağın da peroksit indeksini önemli düzeyde arttırmış, çoklu doymamış yă̆ asidi profillerini değiştirmiştir. Mikrodalga 1sıtmanın kolza yağına oranla aspir yağını daha fazla etkilediği bulunmuştur (Pop, 2018). Farklı yağ asidi bileşimlerine sahip üç bitkisel yağa (findık, kanola ve mısır yağlarının) uygulanan mikrodalga 1sıtma, yağların bulanıklık, serbest yağ asitliği ve peroksit değeri ile konjüge dien ve trien değerleri ile oksidatif indüksiyon sürelerini değiştirmiştir (Arifoğlu ve Öğütçü, 2019). Tüm yağ örneklerinin serbest yağ asitliği, peroksit, konjüge dien ve konjüge trien değerleri, mikrodalga 1sıtma süresine bağlı olarak artmış, oksidatif indüksiyon süreleri ise düşmüştür. Mikrodalga 1sıtma, yağların türbidite değerlerini etkilememiştir (Arifoğlu ve Öğütçü, 2019).

Mikrodalga 1sıtmanın protein özelliklerine olan etkisi, Vanga vd. (2020) tarafindan incelenmiştir (Çizelge 2). $85^{\circ} \mathrm{C}^{\prime}$ de 10 dakikalık mikrodalga uygulamas1, soya sütünün sindirilebilirliğini, mikrodalga uygulanmamıs örneklere kıyasla \% 93 oranında arttırmıştır. Mikrodalga uygulaması, tripsin inhibitörlerinin aktivitesini azaltmıs, proteinlerin ikincil yapılarını değiştirerek soya sütünün sindirilebilirliğini iyileştirmiştir.

\section{Mikrodalga teknolojisinin doğal biyopolimerlerin kaynağından ekstraksiyonunda fonksiyonlan ve ekstraksiyon sonrası çeşitli özellikleri üzerine etkileri:}

Mikrodalga 1sitma, doğal biyopolimerlerin modifikasyonunda kullanılabildiği gibi bu polimerlerin kaynağından ekstrakte edilmelerinde de kullanılmaktadır (Mizutani vd., 2019; Karrar vd., 2020). Mizutani vd. (2019) yaptıkları çalışmada, soya fasulyesi tohumlarının düşük nem koşullarında otoklav ve mikrodalgada 1sıtılmasının, soya fasulyesi bileşenleri (proteinler ve yă̆) üzerindeki etkilerini incelemişlerdir. Mikrodalga 1sitma, otoklav uygulamasina oranla daha avantajlı bulunmuştur. Proteinler, kısmen denatüre olmuş, tohum içindeki yağ, tohumdan daha kolay ekstrakte edilebilmiştir (Çizelge 2). Vidalı pres ile ekstrakte edilen gurum tohumu yağına mikrodalga uygulamasıyla yağın yağ asidi profilinde küçük farklilıklar gözlenmiştir (Karrar vd., 2020). Mikrodalga 1sıtma süresindeki artış, yağın renk değerini arttırmışır. Genel olarak, mikrodalga 1sıtma, gurum tohumu yağının kimyasal kalitesini ve oksidatif stabilitesini iyileştirmiştir (Karrar vd., 2020).

\section{Ultrases teknolojisinin doğal biyopolimerler üzerine etkisi}

Ultrases teknolojisinin çeşitli doğal biyopolimerler üzerine olan etkilerinin incelendiği çalışmalar, Çizelge 3' te özetlenmiştir. Farklı yoğunluklarda ve sürelerde ultrases uygulamas1, çeşitli kaynaklardan elde edilen nişastaların fiziksel, termal ve reolojik özellikleri ile x-sşını kırınım desenlerini değiştirmiştir (Jambrak vd., 2010; Hu vd., 2014; Monroy vd., 2018; Li vd., 2019). Farklı yoğunluklarda ve sürelerde ultrases uygulamasıyla nişastanın jelatinizasyon entalpisi azalmış, şişme gücü ve çözünürlüğü ile su tutma kapasitesi artmış ve nişasta granüllerinde kristal bölge tahrip olmuştur (Jambrak vd., 2010). Farklı sürelerde çift frekanslı ve tek frekanslı ultrases uygulamasi, etanol çözeltisi içinde süspanse edilmiş mısır nişastalarının özelliklerinde ve yapılarında değişikliklere neden olmuştur. Çift frekanslı ultrases uygulamasıyla nişastanın şeffaflığ iyileşmiş, donma-çözülme stabilitesi değişmiş, jelatinizasyon entalpisi değeri ve kristalinitesi 
azalmışıı (Hu vd., 2014). Ultrases uygulaması, manyok nişasta granüllerinde yapisal düzensizliklere, mikroyapılarında ve kristalizasyon seviyelerinde değişime neden olmuştur. Ultrases uygulama koşulları değiştirilerek farklı nişasta türevleri elde edilebilmiştir (Monroy vd., 2018). $700 \mathrm{~W}$ güçte farklı sürelerde ultrases uygulaması, dar1 nişastasının in vitro enzimatik sindirilebilirliğini, jelatinizasyon entalpisini, şişme gücünü ve şeffaflığını arttırmış, kristalinitesini ve pik viskozitesini azaltmış, nişasta granüllerinin orijinal görünümüne tamamen zarar vermeden sadece çatlak ve gözenek oluşturmuştur ( $\mathrm{Li}$ vd., 2019).

Ultrases uygulamasının $\% 1^{\prime}$ lik selüloz-su süspansiyonunun morfolojisi, partikül boyutu, kristalinitesi ve kristal boyutu üzerine etkisinin araştırıldığı çalışmada, ultrases uygulamasının selüloz partiküllerini kısa lifler haline dönüştürdügü, 1 ve 5 saatlik ultrases uygulamas1 sonrasinda selüloz lif uzunluğunun $80-120 \mu \mathrm{m}$ ' den sirasiyla $30-50 \mu \mathrm{m}$ ve $20-30 \mu \mathrm{m}$ ' ye düştüğü bulunmuştur. Partikül ve kristal boyutundaki en yüksek düşüş, ultrases uygulamasının ilk 1 saatinde meydana gelmiş, zaman ilerledikçe ultrases etkinliği düşmüştür. Farklı sıcaklıkta ultrases uygulamas1, istatistiksel olarak selülozun özelliklerinde önemli bir değişime neden olmamıştır (Sumari vd., 2013).

Yüksek yoğunluklu ultrases uygulamasının farklı molekül ağırlığına sahip hidroksipropil metil selülozların (HPMC) moleküler ve fonksiyonel özellikleri (bulutlanma noktası, jelleşme sıcaklı̆̆1, termal geçişler, görünür viskozite ve su hareketliliği) üzerine etkilerini inceleyen çalışma sonuçlarına göre HPMC' ye ultrases uygulaması, konsantrasyona bağlı geçici kümelerin oluşumuna ve bulutlanma noktasının düşmesine neden olmuştur. Ultrases uygulaması, HPMC' nin emülsifiye edici davranışını etkilememiştir. Yüksek molekül ağırlıklı HPMC için viskozite ve su hareketliliğindeki değişiklikler, düşük moleküler ağırlıklı HPMC' ye oranla daha belirgin bulunmuştur (Camino vd., 2009).

Çizelge 3. Ultrases teknolojisinin doğal biyopolimerler üzerine etkisi

\begin{tabular}{|c|c|c|c|c|}
\hline Biyopolimer & $\begin{array}{l}\text { Biyopolimer } \\
\text { tipi/kaynağ1 }\end{array}$ & $\begin{array}{l}\text { Ultrases Uygulama } \\
\text { Koşulları }\end{array}$ & Biyopolimer Üzerine Etkileri & Kaynak \\
\hline Nişasta & Misır nişastası & $\begin{array}{l}100,300 \text { ve } 400 \mathrm{~W} \\
\text { güç, farklı } \\
\text { yoğunluklarda }(34, \\
\left.55,73 \mathrm{~W} \mathrm{~cm}^{-2}\right), 15 \\
\text { ve } 30 \mathrm{dk}, \% 100 \\
\text { sabit genlik }\end{array}$ & $\begin{array}{l}\text { Jelatinizasyon entalpisinde azalıs, } \\
\text { şişme gücü, çözünürlük ve su } \\
\text { tutma kapasitesinde artış ve } \\
\text { granüllerin kristal bölgesinde } \\
\text { tahrip }\end{array}$ & $\begin{array}{l}\text { Jambrak } \\
\text { vd., } 2010\end{array}$ \\
\hline Nişasta & Misır nişastas1 & $\begin{array}{l}\text { Çift frekansl } \\
(20+25 \mathrm{kHz}) \text { ve } \\
\text { tek frekansli (20 } \\
\mathrm{kHz}, 25 \mathrm{kHz}), \\
30^{\circ} \mathrm{C}, \\
0,5,10,15,20,30 \\
\text { ve } 40 \mathrm{dk}\end{array}$ & $\begin{array}{l}\text { Nişasta şeffaflığında iyileşme, } \\
\text { donma-çözülme stabilitesinde } \\
\text { belirgin değişim, jelatinizasyon } \\
\text { entalpisi ve kristalinitede azalma }\end{array}$ & $\begin{array}{l}\mathrm{Hu} \text { vd., } \\
2014\end{array}$ \\
\hline Nişasta & $\begin{array}{l}\text { Manyok } \\
\text { nişastas1 }\end{array}$ & $\begin{array}{l}\text { \% } 40 \text { genlik, } 750 \mathrm{~W} \\
\text { güç, } 0,5,10 \text { ve } 20 \\
\text { dk }\end{array}$ & $\begin{array}{l}\text { Nişasta granüllerinde yapısal } \\
\text { düzensizlikler, mikroyapilarında } \\
\text { ve kristalizasyon seviyelerinde } \\
\text { değişim }\end{array}$ & $\begin{array}{l}\text { Monroy } \\
\text { vd., } 2018\end{array}$ \\
\hline Nişasta & Darı nişastası & $\begin{array}{l}25+40+80 \mathrm{kHz} \\
\text { frekans, } 700 \mathrm{~W} \\
\text { güçte, } 15,30,45 \mathrm{ve} \\
60 \mathrm{dk}\end{array}$ & $\begin{array}{l}\text { İn vitro enzimatik sindirilebilirlik, } \\
\text { jelatinizasyon entalpisi, şişme gücü } \\
\text { ve şeffaflıkta artış, kristalinite, pik } \\
\text { viskozitesinde azalış }\end{array}$ & $\begin{array}{l}\mathrm{Li} \text { vd., } \\
2019\end{array}$ \\
\hline
\end{tabular}


Çizelge 3. devam

\begin{tabular}{|c|c|c|c|c|}
\hline Biyopolimer & $\begin{array}{l}\text { Biyopolimer } \\
\text { tipi/kaynağ1 }\end{array}$ & $\begin{array}{l}\text { Ultrases Uygulama } \\
\text { Koşulları }\end{array}$ & Biyopolimer Üzerine Etkileri & Kaynak \\
\hline Selüloz & $\begin{array}{l}\% 1 \text { ' lik selüloz- } \\
\text { su süspansiyonu }\end{array}$ & $\begin{array}{l}28 \mathrm{kHz}, 300 \mathrm{~W}, 40 \\
\text { ve } 60^{\circ} \mathrm{C} \\
1-5 \mathrm{sa}\end{array}$ & $\begin{array}{l}\text { Selüloz partiküllerinde kısa lifler } \\
\text { haline dönüşüm, ultrases } \\
\text { uygulamasının ilk } 1 \text { saatinde } \\
\text { partikül ve kristal boyutunda en } \\
\text { yüksek düşüș }\end{array}$ & $\begin{array}{l}\text { Sumari } \\
\text { vd., } 2013\end{array}$ \\
\hline Gam & $\begin{array}{l}\text { Hidroksipropil } \\
\text { metil selüloz } \\
\text { (HPMC) }\end{array}$ & $\begin{array}{l}20 \mathrm{kHz} \text { frekans, } \\
\% 20 \text { genlik }\end{array}$ & $\begin{array}{l}\text { Konsantrasyona bağlı geçici } \\
\text { kümelerin oluşumu ve bulutlanma } \\
\text { noktasinda düşüş, yüksek } \\
\text { moleküler ağırlıklı HPMC için } \\
\text { viskozite ve su hareketliliğinde } \\
\text { daha belirgin değişim }\end{array}$ & $\begin{array}{l}\text { Camino } \\
\text { vd., } 2009\end{array}$ \\
\hline Protein + Gam & $\begin{array}{l}\text { Balık } \\
\text { miyofibriler } \\
\text { proteini } \\
\text { ksantan zamk1 }\end{array}$ & $\begin{array}{l}20 \mathrm{kHz} \text { frekans, } 0 \\
150,300,450 \text { ve } \\
600 \mathrm{~W} \text { güç }\end{array}$ & $\begin{array}{l}\text { 300W' lik ultrases uygulamasıyla, } \\
\text { emülsiyonun parçacık boyutu, } \\
\text { yüzey gerilimi ve görünür } \\
\text { viskozitesinde düşüş, depolama } \\
\text { stabilitesinde artış }\end{array}$ & $\begin{array}{l}\text { Xiong } \\
\text { vd., } 2019\end{array}$ \\
\hline Protein & $\begin{array}{l}\% 10 \text { peyniralt1 } \\
\text { suyu proteini } \\
\text { konsantresi, } \\
\text { soya proteini } \\
\text { izolat1 r ve } \\
\text { yumurta beyazı } \\
\text { proteini }\end{array}$ & $\begin{array}{l}20 \mathrm{dk} \text { boyunca } 20 \\
\mathrm{kHz} \text { frekans, } 4,27 \\
\pm 0,71 \mathrm{~W} \text { güç ve } \\
\% 20 \text { genlik }\end{array}$ & $\begin{array}{l}\text { Tüm protein solüsyonlarının } \\
\text { kıvam indekslerinde düşüşs, yüzey } \\
\text { hidrofobitelerinde artış }\end{array}$ & $\begin{array}{l}\text { Arzeni } \\
\text { vd., } 2012\end{array}$ \\
\hline Protein & Zein & $\begin{array}{l}\text { Çift frekanslı }(40 \pm \\
2 \text { ve } 68 \pm 2 \mathrm{kHz}) \\
0,10,20,30,40,50 \\
\text { ve } 60 \mathrm{dk}\end{array}$ & $\begin{array}{l}\text { Uygulama süresinin artmasıyla } \\
\text { proteinlerin çözünürlüğ̈nde } \\
\text { artma, uzun sonikasyon süreleriyle } \\
\text { zeinin ortalama parçacık boyutu } \\
\text { ve boyut dağlliminda artma, çift } \\
\text { frekanslı ultrases uygulaması ile } \\
\text { zeinin yapisal ve fiziksel } \\
\text { özelliklerinde değiş̧im }\end{array}$ & $\begin{array}{l}\text { Ren vd., } \\
2015\end{array}$ \\
\hline Protein & $\begin{array}{l}\text { Siğıir } \\
\text { miyofibriler } \\
\text { proteini }\end{array}$ & $\begin{array}{l}20 \mathrm{kHz} \text { frekans, } \\
100 \text { ve } 300 \mathrm{~W} \text { güç, } \\
0,10,20 \text { ve } 30 \mathrm{dk}\end{array}$ & $\begin{array}{l}\text { Uygulama süresi ve gücün } \\
\text { artmastyla viskozitede azalma, } \mathrm{pH} \text {, } \\
\text { reaktif sülfidril içeriği, su tutma } \\
\text { kapasitesi ve jel mukavemetinde } \\
\text { en yüksek değer, ultrases } \\
\text { uygulama sonrasi proteinlerin } \\
\text { partikül boyutunda düşüş }\end{array}$ & $\begin{array}{l}\text { Amiri } \\
\text { vd., } 2018\end{array}$ \\
\hline Protein & Soya sütü & $\begin{array}{l}25 \mathrm{kHz}, 400 \mathrm{~W}, 1 \\
4,8,12 \text { ve } 16 \mathrm{dk}\end{array}$ & $\begin{array}{l}\text { Tripsin inhibitör aktivitesinde } \\
\text { azalma, sindirilebilirlikte iyileşme }\end{array}$ & $\begin{array}{l}\text { Vanga } \\
\text { vd., } 2020\end{array}$ \\
\hline
\end{tabular}

Miyofibriler protein ve ksantan zamk 1 ile stabilize edilmiş emülsiyona $300 W^{\prime}$ lik ultrases uygulamas1, emülsiyonun parçacık boyutunu ve yüzey gerilimini ve görünür viskozitesini azaltmış, depolama stabilitesini arttırmıştır (Xiong vd., 2019). 
Yüksek yoğunluklu ultrases uygulaması, $\mathrm{pH}^{\prime}$ s1 6.5-7.1' e ayarlanmış protein solüsyonlarının (\%10’ luk peyniraltı suyu proteini konsantresi, soya proteini izolatı ve yumurta beyazı proteini) kıvam indekslerini düşürmüş, yüzey hidrofobitelerini arttırmıştır. Yumurta beyazı proteininin jelleşme performans1, yüksek yoğunluklu ultrases uygulaması ile değişmemiş, peyniraltı suyu proteini konsantresi daha yüksek bir elastik karakter sergilemiştir (Arzeni vd., 2012). Çift frekanslı (bir frekanstan diğerine geçerek) ultrases uygulamas1, zeinin yapisal ve fiziksel özelliklerini değiştirmiştir (Ren vd., 2015). Ultrases işlemine tabi tutulan zein proteinlerinin çözünürlüğ̈̈, uygulama süresi arttıkça önemli ölçüde artmıştır. Daha uzun sonikasyon süreleri (> 20 dakika) için zeinin ortalama parçacık boyutu ve boyut dağılımı artmıştır. Ultrases uygulamasıyla zein mikroyapısı değissmiş, birçok mikro delik görülmüştür (Ren vd., 2015). Yüksek yoğunluklu ultrases uygulanması, siğır miyofibriler proteinlerinin fizikokimyasal, fonksiyonel ve reolojik özelliklerini değiştirmiştir. pH, reaktif sülfidril içeriği, su tutma kapasitesi ve jel mukavemetinde en yüksek değer 300W' de $30 \mathrm{dk}$ ultrases uygulamasina tabi tutulan örneklerde elde edilmiştir. Proteinlerin partikül boyutu, ultrases dalgalarının kavitasyon kuvveti nedeniyle ultrases uygulamasından sonra azalmıştır. 100 ve $300 \mathrm{~W} 30$ $\mathrm{dk}$ ultrases uygulamaları hariç olmak üzere ultrases ile işlem gören örneklerin kontrolden daha sert ve elastik olduğu bulunmuştur. Sonikasyonun süresi ve gücü arttıkça viskozitede azalma meydana gelmiştir (Amiri vd., 2018). Ultrases uygulamas1, tripsin inhibitör aktivitesinin azaltılmasında ve proteinlerin ikincil yapilarını değiştirerek soya sütünün sindirilebilirliğinin iyileştirilmesinde potansiyel uygulamalardır. 16 dakikalık ultrases işlemine tabi tutulmuş soya sütünün tripsin inhibitör aktivitesi, ultrases uygulanmamış örneklere kıyasla \%52 azalmıştır (Vanga vd., 2020).

\section{Kombine uygulamaların doğal biyopolimerler üzerine etkileri Kiz1lötesi-mikrodalga kombinasyonunun doğal biyopolimerler üzerine etkileri}

Kızılötesi-mikrodalga kombinasyon 1sıtma, çeşitli nişastaların fiziksel, reolojik ve termal özelliklerini değiştirmiştir (Shah vd., 2016; Çengelköy Köz, 2019) (Çizelge 4). Hint kestanesinden elde edilen nişastaya sabit güçte farklı zaman aralıkları ile arka arkaya kızı̈ötesi ve mikrodalga 1sıtma uygulamas1, hidroksil gruplarının fazlalaştırmış ve 3240 1/cm' de tepe yoğunluğunun artmasina sebep olmuştur. Uygulanan radyasyonla nişasta granüllerinin yüzeyinde çatlaklar oluşmuş, su emme kapasitesinde ve ş̧1k geçirgenliğinde artı̧; amiloz içeriği, $\mathrm{pH}$ ve sinerezis özelliklerinde azalma meydana gelmiştir. Hem mikrodalga hem kızı̈ötesi uygulamaları, nişastanın antioksidan aktivitesini iyileştirmiştir (Shah vd., 2016).

Çizelge 4. Kızılötesi-mikrodalga kombinasyonun doğal biyopolimerler üzerine etkileri

\begin{tabular}{|c|c|c|c|c|c|}
\hline Biyopolimer & $\begin{array}{l}\text { Biyopolimer } \\
\text { tipi/kaynağ1 }\end{array}$ & $\begin{array}{l}\text { Kuzılötesi- } \\
\text { Mikrodalga } \\
\text { Kombinasyonu } \\
\text { Uygulama } \\
\text { Koşulları }\end{array}$ & $\begin{array}{l}\text { Biyopolimer } \\
\text { Etkileri }\end{array}$ & Kaynak & \\
\hline Nişasta & $\begin{array}{l}\% 22 \pm 3 \text { neme } \\
\text { tavlanmiş hint } \\
\text { kestanesinden } \\
\text { elde edilen } \\
\text { nişasta }\end{array}$ & $\begin{array}{l}\text { Sabit güçte, } \\
15,30 \text { ve } 45 \mathrm{~s}\end{array}$ & $\begin{array}{l}\text { Su emme kapasitesi ve } 1 s ̧ 1 \mathrm{k} \\
\text { geçirgenliğinde artış, } \\
\text { amiloz içeriği, pH ve } \\
\text { sinerezis özelliklerinde } \\
\text { azalma, antioksidan } \\
\text { aktivitesinde iyileşme }\end{array}$ & Shah vd., 2016 & \\
\hline Nişasta & $\begin{array}{l}\% 15 \text { ve } \% 25 \\
\text { neme tavlanmiş } \\
\text { misır nişastası }\end{array}$ & $\begin{array}{l}\text { \%20k1zılötesi- } \\
\% 20 \text { mikrodalga } \\
\text { güç15dk } \\
\% 30 \mathrm{k} 1 z 1 \text { ötesi- } \\
\% 30 \text { mikrodalga } \\
\text { güç 7,5dk }\end{array}$ & $\begin{array}{l}\text { Nişastanın fiziksel, } \\
\text { reolojik ve termal } \\
\text { özelliklerinde iyileşme }\end{array}$ & $\begin{array}{l}\text { Çengelköy } \\
2019\end{array}$ & Köz, \\
\hline
\end{tabular}


Kızı̈ötesi ve mikrodalga uygulamasının eş zamanlı yapıldığı çalışmada, farklı nem içeriğine tavlanmış mısır nişastaları, farklı güç ve sürelerde kızı̈ötesi ve mikrodalga 1sitmaya tabi tutulmuştur. Nişastaların fiziksel, optik, morfolojik, termal özellikleri ile X-ışını kırınım desenleri, modifikasyon işlemi ile belirgin bir şekilde değişmiştir (Çengelköy Köz, 2019).

\section{Ultrases-mikrodalga kombinasyonun doğal biyopolimerler üzerine etkileri}

Ultrases-mikrodalga uygulaması, doğal biyopolimerlerin fiziksel, reolojik ve termal özelliklerini değiştirmiştir (Çizelge 5). Guar gamın sulu çözeltisinin depolimerizasyonu için tek tek ve kombinasyon halinde ultrases ve mikrodalga teknolojilerinin uygulandığ çalışmada, tekli uygulamalardan ultrases teknolojisinin, kombine uygulamalardan ise önce mikrodalga ardindan ultrases uygulamasinin guar gamin depolimerizasyonunda daha etkili olduğu bulunmuştur (Prajapat and Gogate, 2015). Kestane nişastasında ikili modifikasyon (ultrases- mikrodalga modifiye nişasta ve mikrodalgaultrases modifiye nişasta) uygulaması, ultrases ve mikrodalga işleminin sinerjistik etkisine bağlı olarak, sadece ultrases veya mikrodalga uygulamasına nazaran daha belirgin değişimlere neden olmuştur (Wang vd., 2020). Ultrasesmikrodalga kombinasyon uygulamasiyla nişastaların şişme gücü, jelatinizasyon entalpi ve kristalinite değerleri düşmüş, daha zayıf çiftkırınım özelliği göstermiş ve nişastanın katmanlı yapısı ve çift sarmal yapısı daha ciddi şekilde bozulmuştur. Ayrica ultrases-mikrodalga modifiye nişasta örneklerinin yağ emme kapasitesi; mikrodalga-ultrases modifiye nişasta örneklerinin ise su emme kapasitesi en yüksek bulunmuş ve mikrodalga-ultrases modifiye nişasta örneklerinin donma-çözünme kararlllığ1 en iyi çıkmıştır. Tekli veya ikili modifikasyondan bağımsız olarak ultrases ve mikrodalga uygulanmış örneklerin şişme gücü, maksimum, incelme sonrası, son ve karıștırma viskoziteleri ve çirişlenme sıcaklıkları azalmıştır (Wang vd., 2020).

Çizelge 5. Ultrases-mikrodalga kombinasyonun doğal biyopolimerler üzerine etkileri

\begin{tabular}{|c|c|c|c|c|}
\hline Biyopolimer & $\begin{array}{l}\text { Biyopolimer } \\
\text { tipi/kaynağ1 }\end{array}$ & $\begin{array}{l}\text { Ultrases-Mikrodalga } \\
\text { Kombinasyonu } \\
\text { Uygulama Koşulları }\end{array}$ & $\begin{array}{l}\text { Biyopolimer Üzerine } \\
\text { Etkileri }\end{array}$ & Kaynak \\
\hline Gam & Guar gam & $\begin{array}{l}\text { Ultrases; } 20 \mathrm{kHz} \text { sabit } \\
\text { frekans, } 240 \mathrm{~W} \text { güç } \\
\text { Mikrodalga; } 800 \mathrm{~W} \\
\text { nominal güce ve değişken } \\
\text { güç ç1k1ş1 } \% 17, \% 33 \text {, } \\
\% 55, \% 77 \text { ve } \% 100\end{array}$ & $\begin{array}{l}\text { Kombine uygulamalarda } \\
\text { önce mikrodalga ardindan } \\
\text { ultrases uygulamasiyla } \\
\text { daha etkili } \\
\text { depolimerizasyon }\end{array}$ & $\begin{array}{l}\text { Prajapat ve } \\
\text { Gogate, } 2015\end{array}$ \\
\hline Nişasta & $\begin{array}{l}\text { Kestane } \\
\text { nişastas1 }\end{array}$ & $\begin{array}{l}\text { Ultrases } 20 \mathrm{kHz} \text { frekans, } \\
500 \mathrm{~W} \text { güçte, } 60 \mathrm{dk}, \\
\text { mikrodalga } 2450 \mathrm{MHz} \\
\text { frekans, } 30 \mathrm{~W} \text { güçte, } 90 \mathrm{~s}\end{array}$ & $\begin{array}{l}\text { Kombine uygulamayla } \\
\text { nişastanın şişme gücü, } \\
\text { kristallinite, jelatinleşme } \\
\text { entalpisinde düşüş ve daha } \\
\text { zayıf çift-kırınım özelliği, } \\
\text { nişastanın katmanlı yapısı } \\
\text { ve çift sarmal yapısında } \\
\text { bozulma, ultrases- } \\
\text { mikrodalga modifiye } \\
\text { nişasta örneklerinde en } \\
\text { yüksek yağ emme } \\
\text { kapasitesi, mikrodalga- } \\
\text { ultrases modifiye nişasta } \\
\text { örneklerinde en yüksek su } \\
\text { emme kapasitesi ve en iyi } \\
\text { donma-çözülme kararlıllğı }\end{array}$ & $\begin{array}{l}\text { Wang vd., } \\
2020\end{array}$ \\
\hline
\end{tabular}


Çizelge 5. devam

\begin{tabular}{|c|c|c|c|c|}
\hline Biyopolimer & $\begin{array}{l}\text { Biyopolimer } \\
\text { tipi/kaynağ1 }\end{array}$ & $\begin{array}{l}\text { Ultrases-Mikrodalga } \\
\text { Kombinasyonu Uygulama } \\
\text { Koşulları }\end{array}$ & Biyopolimer Üzerine Etkiler & Kaynak \\
\hline Lipid & $\begin{array}{l}\text { Sorgum } \\
\text { tohumu }\end{array}$ & $\begin{array}{l}\text { Ultrases + mikrodalga } \\
5 \mathrm{dk} / \% 40+15 \mathrm{~s} / 450 \mathrm{~W} \\
5 \mathrm{dk} / \% 60+15 \mathrm{~s} / 700 \mathrm{~W} \\
10 \mathrm{dk} / \% 40+30 \mathrm{~s} / 450 \mathrm{~W} \\
10 \mathrm{dk} / \% 60+30 \mathrm{~s} / 700 \mathrm{~W}\end{array}$ & $\begin{array}{l}\text { Mikrodalga ve ultrases } \\
\text { kombinasyonunun } \\
\text { yüksek kaliteli sorgum yağ1 } \\
\text { elde etmek için en iyi yönten } \\
\text { olması }\end{array}$ & $\begin{array}{l}\text { Hassan vd., } \\
2017\end{array}$ \\
\hline Nişasta & Misır nişastası & $\begin{array}{l}\text { Süre/Mikrodalga/ } \\
\text { Ultrases / Sicaklik } \\
40 \mathrm{dk} / 140 \mathrm{~W} / 350 \mathrm{~W} / 54^{\circ} \mathrm{C} \\
45 \mathrm{dk} / 150 \mathrm{~W} / 400 \mathrm{~W} / 56^{\circ} \mathrm{C} \\
50 \mathrm{dk} / 160 \mathrm{~W} / 450 \mathrm{~W} / 58^{\circ} \mathrm{C}\end{array}$ & $\begin{array}{l}\text { Nişastanın kalitesinde } \\
\text { iyileşme, tek düze gözenek } \\
\text { yoğunluğuna sahip nişasta } \\
\text { eldesi }\end{array}$ & $\begin{array}{l}\text { Liu vd., } \\
2012\end{array}$ \\
\hline Protein & $\begin{array}{l}\text { Balik } \\
\text { miyofibriler } \\
\text { proteini }\end{array}$ & $\begin{array}{l}\text { Çeşitli ultrasonik güç (100, } \\
200,300 \text { ve } 400 \mathrm{~W}), \mathrm{Sabit} \\
\text { mikrodalga gücü }(100 \mathrm{~W}), \\
\text { ultrason frekans1 } 28 \mathrm{kHz}, \\
\text { mikrodalganın frekans1 } \\
2450 \mathrm{~Hz}\end{array}$ & $\begin{array}{l}\text { Kombine ultrason- } \\
\text { mikrodalga uygulamasiyla } \\
\text { antioksidan özellikler ve } \\
\text { termal stabilitede iyileşme, } \\
\text { miyofibriler proteinlerden } \\
\text { hidrolizat elde ederken } \\
\text { hidroliz reaksiyonuna } \\
\text { proteinlerin daha açık hale } \\
\text { gelmesi ve hidrolizat } \\
\text { veriminin daha yüksek olmas }\end{array}$ & Li vd., 2020 \\
\hline Protein & $\begin{array}{l}\text { Çin mersin } \\
\text { balığ } 1\end{array}$ & $\begin{array}{l}\text { Mikrodalga } 10 \text { ila } 800 \mathrm{~W} \\
\text { arasında değişen güçte ve } \\
2.450 \mathrm{MHz} \text { frekansta, } \\
\text { ultrases } 50 \mathrm{~W} \text { (sabit) güçte } \\
\text { ve } 40 \mathrm{kHz} \text { frekansta, } \\
4,8,15 \text { ve } 25 \mathrm{dk}\end{array}$ & $\begin{array}{l}\text { Teknolojilerin birarada } \\
\text { uygulanmasıyla enzimatik } \\
\text { hidroliz yönteminin } \\
\text { etkinliğinde ve örneklerin } \\
\text { antioksidan aktivitelerinde } \\
\text { artış }\end{array}$ & $\begin{array}{l}\text { Noman vd., } \\
2020\end{array}$ \\
\hline
\end{tabular}

Ultrases-mikrodalga kombinasyon uygulamasının dogal biyopolimerlerin kaynağından ekstraksiyonunda fonksiyonları ve ekstraksiyon sonrası çeşitli özellikleri üzerine etkileri:

Ultrases ve mikrodalga kombinasyon uygulamas1, sorgum tohumlarının yağ asitleri bileşimini ve yağ verimini etkilemiştir (Hassan vd., 2017). Yüksek kaliteli sorgum yağ1 elde etmede ultrasesmikrodalga kombinasyonu, tek başına mikrodalga ya da tek başına ultrases uygulamalarına kiyasla en iyi yöntem olmuştur (Çizelge 5).

\section{Ultrases-mikrodalga kombinasyon} uygulamasının doğal biyopolimerlerin enzimlerle hidrolizinde fonksiyonlar1 ve ekstraksiyon sonrası çeşitli özellikleri üzerine etkileri:

Geleneksel enzim hidroliz yöntemi, ultrasesmikrodalga uygulaması ile birleştirildiğinde, mısır nişastasının kalitesi iyileşmiş, tek düze gözenek yoğunluğuna sahip nişasta elde edilmiştir (Liu vd., 2012) (Çizelge 5).

Ultrases-mikrodalga kombinasyon uygulamas1, miyofibriler protein peptidlerinin ve Çin mersin balığ1 protein hidrolizatlarının antioksidan 
özelliklerini, termal stabilitelerini iyileştirmiş, enzimatik hidroliz yönteminin etkinliğini arttırmıştır (Li vd., 2020; Noman vd., 2020).

\section{SONUÇ}

Kızılötesi, mikrodalga ve ultrases teknolojileri, doğal biyopolimerlerin modifikasyonunda başarıyla kullanılmaktadır. Kullanılan bu teknolojilerin proses koşullarına (kızılötesi için frekans, dalgaboyu, güç, süre; mikrodalga için frekans, güç, süre; ultrases için frekans, yoğunluk, süre, vb.), uygulama ekipmanına ve biyopolimerlerin tipine ve elde edildikleri kaynaklara bağlı olarak biyopolimerlerin özelliklerinde meydana getirdikleri değişimler farklılık göstermektedir. Kızılötesi uygulamas1, nişastanın granül yapısını ve reolojik özelliklerini değiştirmiş ve nişastanın elde edildiği kaynağa bağl1 olarak bu değişimlerin düzeyi farklılık göstermiştir. Mikrodalga uygulaması, nişastanın şişme gücünü, amiloz içeriğini, jelatinizasyon entalpisini ve viskozitesini azaltırken çiriş stabilitesini, çirişlenme sıcaklığını arttırmıș, yağların oksidatif stabilitelerini değiştirmiştir. Ultrases uygulamas1, polimerlerin morfolojisini, boyutlarını, reolojik ve çözünürlük özelliklerini değiştirmiş, polisakkaritlerin ve yağların kaynağından ultrases yardımıyla ekstraksiyonunda verimi arttırmış, ekstraksiyon süresini kısaltmıştır. Ayrica polimerlerin enzimatik hidrolizini kolaylaştırmıştır. Kızılötesi-mikrodalga ve ultrases-mikrodalga teknolojilerinin birarada kullanılmasıyla sinerjistik bir etki oluşturularak polimerlerin yapısal ve fonksiyonel özelliklerinde daha kısa sürede daha belirgin değişiklikler meydana getirilmiştir. Bu makale kapsamında ele alınan teknolojiler, gıda endüstrisinde kullanılmak üzere doğal biyopolimerlerin fonksiyonelliklerinin geliştirilmesinde yüksek potansiyele sahiptir. Kızılötesi ve kızılötesi-mikrodalga uygulamalarının nişasta dışındaki polimerler üzerine etkileri konularında sınırlı sayıda çalışma yer almaktadır. Bu kapsamda daha fazla veri üretilmesine ihtiyaç vardır. Diğer yandan, biyopolimerlerin tipine ve elde edildiği kaynağa bağlı olarak uygulanan işlem koşullarının farklılık göstermesi, kullanılan ekipmanların standart özelliklere sahip olmamaları ve bilimsel çalışmalarda deneysel tasarımın laboratuvar ölçekli ekipmanlar kullanılarak yapılmış olması, bu teknolojilerin endüstriyel olarak yaygınlaştırılmalarını sinırlandırmaktadır. $\mathrm{Bu}$ teknolojilerin endüstriyel ölçekte kullanımlarının yaygınlaştırılması için biyopolimerin tipi ve özelliklerine özgü endüstriyel ölçekte standart yeni tasarımlar gerçekleştirilebilir.

\section{ÇIKAR ÇATIŞMASI BEYANI}

Yazarlar, bu makale ile ilgili olarak başka kişiler ve/veya kurumlar arasında çıkar çatışması olmadığını beyan etmektedir.

\section{YAZAR KATKILARI}

Tüm yazarlar, makalenin yazilmasinda ve yayınlanmasında katkı sağlamışlardır. Makalenin hazırlanmasında başka kişi ve/veya kurumların katk1s1 yoktur.

\section{KAYNAKLAR}

Aboud, S.A., Altemimi, A.B., Al-Hilphy, A.R. S., Lee, Y., Cacciola, F. (2019). A comprehensive review on infrared heating applications in food processing. Molecules, 24(22): 4125.

Akyüz A.Ö. (2010). Ultrasesin polimerlere etkileri, İstanbul Teknik Üniversitesi, Fen Bilimleri Enstitüsü, Fizik Mühendisliği Anabilim Dalı Yüksek Lisans Tezi, İstanbul, Türkiye, $141 \mathrm{~s}$.

Amiri A., Sharifian P., Soltanizadeh N. (2018). Application of ultrasound treatment for improving the physicochemical, functional and rheological properties of myofibrillar proteins, Int J Biol Macromol, 111:139-147.

Anderson A.K., Guraya H.S. (2006). Effects of microwave heat-moisture treatment on properties of waxy and non-waxy rice starches, Food Chem, 97(2): 318-323.

Arifoğlu, N., Öğütçü, M. (2019). Effect of microwave heating on quality parameters of hazelnut, Canola and Corn Oils. Akademik Gida, 17(1): 23-29.

Arzeni C., Martinez K., Zema P., Arias A., Perez O.E., Pilosof A.M.R. (2012). Comparative study of high intensity ultrasound effects on food proteins functionality. J Food Eng, 108(3): 463472. 
Balaji, A.B., Pakalapati, H., Khalid, M., Walvekar, R., Siddiqui, H. (2018). Natural and synthetic biocompatible and biodegradable polymers. In: Biodegradable and Biocompatible Polymer Composites, Elsevier, pp. 3-32.

Bhargava, N., Mor, R.S., Kumar, K., Sharanagat, V.S. (2021). Advances in application of ultrasound in food processing: A review. Ultrason Sonochem, 70: 105293.

Bhatia, S. (2016). Natural polymers vs synthetic polymer. In: Natural Polymer Drug Delivery Systems, Springer, pp. 95-118.

Camino N.A., Perez O.E., Pilosof A.M.R. (2009). Molecular and functional modification of hydroxypropylmethylcellulose by high-intensity ultrasound, Food Hydrocoll, 23(4): 1089-1095.

Cui, R.B., Zhu, F. (2021). Ultrasound modified polysaccharides: A review of structure, physicochemical properties, biological activities and food applications. Trends Food Sci Technol,107: 491-508.

Çengelköy Köz, E. (2019). Farklı 1sitma teknolojileri-nem uygulaması ile modifiye edilmiş nişastaların ve bu nişastalardan elde edilen yenilebilir filmlerin özellikleri, Kocaeli Üniversitesi, Fen Bilimleri Enstitüsü, Polimer Bilimi ve Teknolojisi Anabilim Dalı YL Tezi, (Tez Danışmanı: Semin Özge (Özkoç) Keskin), Kocaeli, Türkiye. $131 \mathrm{~s}$.

Dangaran, K., Tomasula, P.M., Qi, P. (2009). Structure and function of protein-based edible films and coatings. In: Edible Films and Coatings for Food Applications, Embuscado M. E. and Huber K. C., (ed.), Springer, pp. 25-56.

Desbrières J., Petit C., Reynaud S. (2014). Microwave-assisted modifications of polysaccharides, Pure Appl Chem, 86(11): 16951706.

Firouz, M.S., Farahmandi, A., Hosseinpour, S. (2019). Recent advances in ultrasound application as a novel technique in analysis, processing and quality control of fruits, juices and dairy products industries: A review. Ultrason Sonochem, 57: 73-88.
Gallo M., Ferrara L., Naviglio D. (2018). Application of ultrasound in food science and technology: A Perspective, Foods, 7(10): 164.

Guimaraes, J.T., Silva, E.K., Alvarenga, V.O., Costa, A.L.R., Cunha, R.L., Sant'Ana, A.S., Freitas, M.Q., Meireles, M.A.A., Cruz, A.G. (2018). Physicochemical changes and microbial inactivation after high-intensity ultrasound processing of prebiotic whey beverage applying different ultrasonic power levels. Ultrason Sonochem, 44: 251-260.

Guo B., Wu J., Hu X., Luo S., Wang H., Xu S., Huang Z., Liu C. (2020). Effects of controlled farinfrared treatment on granular swelling and rheological properties of crop starches, Starch/Stärke, 72(3-4): 1900251.

Hassan, S., Imran, M., Ahmad, N., Khan, M. K. (2017). Lipids characterization of ultrasound and microwave processed germinated sorghum. Lipids Health Dis, 16, 125.

Hu A., Li L., Zheng J., Lu J., Meng X., Liu Y., Rehman R. (2014). Different-frequency ultrasonic effects on properties and structure of corn starch, J Sci Food Agric, 94(14): 2929-2934.

İsmailoğlu, S. Ö., Başman, A. (2015). Effects of infrared heat-moisture treatment on the physicochemical properties of corn starch. Starch/Stärke, 67(5-6): 528-539.

İsmailoğlu, S. Ö., Başman, A. (2016). Physicochemical properties of infrared heatmoisture treated wheat starch, Starch/Stärke, 68(12): 67-75.

Jambrak, A. R., Herceg Z., Subaric, D., Babic, J., Brncic, M., Brncic, S.R., Bosiljkov, T., Cvek D., Tripalo, B., Gelo, J. (2010). Ultrasound effect on physical properties of corn starch. Carbohydr Polym, 79(1): 91-100.

Karrar, E., Sheth, S., Wei, W., Wang, X. (2020). Effect of microwave heating on lipid composition, oxidative stability, color value, chemical properties, and antioxidant activity of gurum (Citrulluslanatus var. Colocynthoide) seed oil. Biocatal Agric Biotechnol, 23,101504. 
Kasaai M.R. (2013). Input power-mechanism relationship for ultrasonic irradiation: Food and polymer applications, J Nat Sci, 05(08): 14-22.

Keskin, S.O. (2003). Effects of different ovens and enzymes on quality parameters of bread. ODTÜ, Fen Bilimleri Enstitüsü, G1da Mühendisliği Anabilim Dalı YL Tezi, (Tez Danışmanı: Servet Gülüm Şumnu, Yardımcı Danışman: Serpil Şahin), Ankara, Türkiye. 135 s.

Keskin, S.O., Sumnu, G., Sahin, S., (2004a). Bread baking in halogen lamp microwave combination oven. Food Res Int, 37(5):489-495.

Keskin, S.O., Sumnu, G., Sahin, S., (2004b). Usage of enzymes in a novel baking process. Nabrung/Food, 48(2):156-160.

Keskin S.O., Ozturk, S., Sahin, S., Köksel, H., Sumnu, G., (2005). Halogen lamp microwave combination baking of cookies. Eur Food Res Technol, 220(5-6): 546-551.

Kumar, Y., Singh, L., Sharanagat, V. L., Patel, A., Kumar, K., (2020). Effect of microwave treatment (low power and varying time) on potato starch: Microstructure, thermo-functional, pasting and rheological properties. Int $J$ Biol Macromol, 155: 27-35.

Lao, YY., Zhang, M., Chitrakar, B., Bhandari, B., Fan, D.C. (2019). Efficient plant foods processing based on infrared heating. Food Rev Int, 35(7): 640663.

Lee, E.H. (2021). A review on applications of infrared heating for food processing in comparison to other industries, In: Innovative Food Processing Technologies: A Comprehensive Review, Article in press, Knoerzer, K. and Muthukumarappan, K. (chief ed.), Elsevier, pp. 431-455. https://doi.org/10.1016/B978-0-08100596-5.22670-X

Li Y., Hu A., Zheng J., Wang X. (2019). Comparative studies on structure and physiochemical changes of millet starch under microwave and ultrasound at the same power., Int J Biol Macromol, 141: 76-84.

Li, Z., Wang, J., Zheng, B., Guo, Z. (2020). Impact of combined ultrasound-microwave treatment on structural and functional properties of golden threadfin bream (Nemipterus virgatus) myofibrillar proteins and hydrolysates. Ultrason Sonochem, 65: 105063.

Liu, Z.D., Yang, Y., Liang, H., Bi, L., Gong, B. (2012). Study on technology of ultrasoundmicrowave assisted improves preparation of porous starch. Mater Manuf Process, Vol. 476478, pp. $744-750$.

Martins, C.P.C., Cavalcanti, R.N., Couto, S.M., Moraes, J., Esmerino, E.A., Silva, M.C., Raices, R.S.L., Gut, J.A.W., Ramaswamy, H.S., Tadini, C.C., Cruz, A.G. (2019). Microwave processing: Current background and effects on the physicochemical and microbiological aspects of dairy products. Compr Rev Food Sci Food Saf, 18(1): 67-83.

Ma S., Fan D., Wang L., Lian H., Zhao J., Zhang H., Chen W. (2015). The impact of microwave heating on the granule state and thermal properties of potato starch, Starch/Starke, 67(5-6): 391-398.

McKenzie, TG., Karimi, F., Ashokkumar, M., Qiao, GG. (2019). Ultrasound and sonochemistry for radical polymerization: Sound synthesis. Chem Eur J, 25(21): 5372-5388.

Mello P.A., Barin J.S., Guarnieri R.A. (2014). Microwave heating, In: Microwave-Assisted Sample Preparation for Trace Element Determination, Elsevier, 59-75.

Mizutani Y., Shibata M., Yamada S., Nambu Y., Hirotsuka M., Matsumura Y. (2019). Effects of heat treatment under low moisture conditions on the protein and oil in soybean seeds, Food Chem, 275:577-584.

Monroy, Y., Rivero, S., Garcia, M.A. (2018). Microstructural and techno-functional properties of cassava starch modified by ultrasound. Ultrason Sonochem, 42: 795-804.

Nadiah, N. I., Uthumporn, U., Syahariza, Z. A. (2015). Effect of microwave heating on potato and tapioca starches in water suspension. Int $J A d v$ Sci Eng Inform Technol, 5(4): 264-271.

Noman, A., Qixing, J., Xu, Y., Abed, S.M., Obadi, M., Ali, A.H., Bukhaiti, W.Q., Xia, W. (2020). Effects of ultrasonic, microwave, and combined 
ultrasonic microwave pretreatments on the enzymatic hydrolysis process and protein hydrolysate properties obtained from Chinese sturgeon (Acipenser sinensis). J Food Biochem, 44: e13292.

Oyeyinka, S. A., Umaru, E., Olatunde, S. J., Joseph, J. K. (2019). Effect of short microwave heating time on physicochemical and functional properties of Bambara groundnut starch. Food Biosci, 28: 36-41.

Patist, A., Bates, D. (2008). Ultrasonic innovations in the food industry: From the laboratory to commercial production. Innov Food Sci Emerg Technol, 9:147-154.

Pop, F. (2018). Effect of microwave heating on quality and fatty acids composition of vegetable oils, Stud Univ Babes-Bolyai Biol, 63(2):43-52.

Prajapat A.L., Gogate P.R. (2015). Depolymerization of guar gum solution using different approaches based on ultrasound and microwave irradiations, Chem Eng Process, 88: 1-9.

Qin X.S., Luo S.Z., Cai J., Zhong X.Y., Jiang S.T., Zheng Z., Zhao Y.Y. (2016). Effects of microwave pretreatment and transglutaminase crosslinking on the gelation properties of soybean protein isolate and wheat glüten mixtures, $J S_{c i}$ Food Agric, 96(10): 3559-3566.

Rastogi, N.K. (2021). Infrared heating in drying operations, In: Innovative Food Processing Technologies: A Comprehensive Review, Article in press, Knoerzer, K. and Muthukumarappan, K. (chief ed.), Elsevier, pp. 456-476. https://doi.org/10.1016/B978-008-100596-5.22671-1

Rattanadecho, P., Makul, N. (2016). Microwaveassisted drying: A Review of the State-of-the-Art. Dry Technol, 34(1):1-38.

Ren X., Wei X., Ma H., Zhou H., Guo J., Mao S., $\mathrm{Hu}$ A. (2015). Effects of a dual-frequency frequency-sweeping ultrasound treatment on the properties and structure of the zein protein. Cereal Chem, 92(2):193-197.

Riadh, M.H., Ahmad, S.A.B., Marhaban, M.H., Soh, A.C. (2015). Infrared heating in food drying: An overview. Dry Technol, 33(3):322-335.
Semwal, J., Meera, M.S. (2020). Infrared radiation: Impact on physicochemical and functional characteristics of grain starch. Starch, 2000112.

Shah, U., Gani, A., Ashwar, B.A., Shah, A., Wani, I.A., Masoodi. F.A. (2016). Effect of infrared and microwave radiations on properties of IndianHorse Chestnut starch. Int J Biol Macromol, 84:166-173.

Singh, V., P. Kumar, P., Sanghi, R. (2012). Use of microwave irradiation in the grafting modification of the polysaccharides-A review, Prog Polym Sci, 37(2):340-364

Souza H.K.S., Campiña J.M., Sousa A.M.M., Silva F., Gonçalves M.P. (2013). Ultrasound-assisted preparation of size-controlled chitosan nanoparticles: Characterization and fabrication of transparent biofilms, Food Hydrocoll, 31(2): 227236.

Stevenson, D.G., Biswas, A., Inglett, (2005). G.E. Thermal and pasting properties of microwaved corn starch. Starch, 57(8):347-353.

Sumari S., Roesyadi A., Sumarno S. (2013). Effects of ultrasound on the morphology, particle size, crystallinity, and crystallite size of cellulose. Sci Study and Res: Chem Chem Eng, 14 (4), pp. 229 239.

Sun H., Shao X., Jiang R., Ma Z., Wang H. (2018). Effects of ultrasonic/microwave-assisted treatment on the properties of corn distarch phosphate/corn straw cellulose films and structure characterization. J Food Sci Technol, 55(4):1467-1477.

Tan, C.P., Man, Y.B.C., Jinap, S., Yusoff, M.S.A. (2001). Effects of microwave heating on changes in chemical and thermal properties of vegetable oils. J Am Oil Chem' Soc, 78(12): 1227-1232.

Türk V. (2013). Ultrasonik depolimerizasyon, Afyon Kocatepe Üniversitesi, Fen Bilimleri Enstitüsü, Fizik Anabilim Dalı Yüksek Lisans Tezi (Tez Danışmanı: Ali Özhan Akyüz), Afon, Türkiye, $62 \mathrm{~s}$.

Uraives, P., Choomjaihan, P. (2019). Some physicochemical properties of tapioca starch during infrared heat treatment, In IOP Conference 
Series: Earth and Environmental Science (Vol. 301, p. 012044). IOP Publishing.

Vanga, S.K., Wang, J., Raghavan, V. (2020). Effect of ultrasound and microwave processing on the structure, in-vitro digestibility and trypsin inhibitor activity of soymilk proteins. LWT-Food Sci Technol, 131: 109708.

Vera A., Tapia C., Abugoch L. (2020). Effect of high-intensity ultrasound treatment in combination with transglutaminase and nanoparticles on structural, mechanical, and physicochemical properties of quinoa proteins/chitosan edible films, Int J Biol Macromol, 144: 536-543.

Verma, D.K., Mahant1, N.K., Thakur, M., Chakraborty, S.K., Srivastav, P.P. (2020). Microwave heating: Alternative thermal process technology for food application. In: Emerging Thermal and Nonthermal Technologies in Food Processing, pp.25-67.

Virkutyte, J. (2015). The use of power ultrasound in biofuel production, bioremediation, and other applications, In: Power Ultrasonics Applications of High-Intensity Ultrasound. pp.1095-1122.

Wang, M., Sun, M., Zhang, YY., Chen, Y., Wu, YW., Ouyang, J. (2019). Effect of microwave irradiation-retrogradation treatment on the digestive and physicochemical properties of starches with different crystallinity. Food Chem, 298: 125015.

Wang, M., Wu, Y., Liu, Y., Ouyang, J (2020). Effect of ultrasonic and microwave dualtreatment on the physicochemical properties of chestnut starch. Polym, 12(8):1718.
Wang, N., Gao, Y., Wang, P., Xie, T., Xiao, Z. (2016). Effect of microwave modification on mechanical properties and structural characteristics of soy protein 1solate and zein blended film. Czech J Food Sci, 34(2): 180-188.

Wang Z., Sun X., Lian Z., Wang X., Zhou J., Ma Z. (2013). The effects of ultrasonic/microwave assisted treatment on the Properties of soy protein isolate/microcrystalline wheat-bran cellulose film. J Food Eng, 114(2): 183-191.

Xiong Y., Li Q., Miao S., Zhang Y., Zheng B., Zhang L. (2019). Effect of ultrasound on physicochemical properties of emulsion stabilized by fish myofibrillar protein and xanthan gum, Innov Food Sci Emerg Technol, 54: 225-234.

Yadav, G., Gupta, N., Sood, M., Anjum, N., Chib, A. (2020). Infrared heating and its application in food processing. J Pharm Innov, 9(2): 142-151.

Yang, Q., Qi, L., Luo, Z., Kong, X., Xiao, Z., Wang, P., Peng, X. (2017). Effect of microwave irradiation on internal molecular structure and physical properties of waxy maize starch. Food Hydrocoll, 69: 473-482.

Y1lmaz Tuncel, N., Tuncel, N.B. (2016). Kızılötesi teknolojisi ve gida işlemedeki kullanımı. Akademike Grda, 14(2): 196-203.

Zhu, F. (2015). Impact of ultrasound on structure, physicochemical properties, modifications, and applications of starch. Trends Food Sci Technol, 43(1): 1-17. 